\title{
Democratization as a Peace Strategy
}

\author{
Yannis A. Stivachtis ${ }^{1} \&$ Stefanie Georgakis ${ }^{2}$ \\ ${ }^{1}$ Department of Political Science, Virginia Tech, VA, USA \\ ${ }^{2}$ School of Public \& International Affairs, Virginia Tech, VA, USA \\ Correspondence: Yannis A. Stivachtis, Department of Political Science, Virginia Tech, 119 Major Williams Hall, \\ Blacksburg, VA 24061, USA. Tel: 1-540-231-5816. E-mail: ystivach@vt.edu
}

Received: March 12, 2013 Accepted: July 3, 2013 Online Published: July 5, 2013

doi:10.5539/res.v5n3p95 URL: http://dx.doi.org/10.5539/res.v5n3p95

\begin{abstract}
The European Union's Security Strategy views the creation of strong and stable states as a prerequisite for international peace and stability. At the same time, the establishment of democratic regimes is seen as fundamental to achieving domestic stability and, as an extension, development. Consequently, democratization and democracy promotion can been seen as strategies that the EU seek to employ in order to achieve international peace and security. The EU seeks to establish an international democratic order through the application of conditionality. The EU does not only apply conditions to states that seek membership of the Union but also to third states, such as the countries included in the European Neighborhood Policy (ENP) or countries that seek to receive financial aid and development assistance from the European Union. In so doing, the article analyzes how the policy of conditionality applies to each different case.
\end{abstract}

Keywords: democratization, democracy promotion, conditionality, European neighborhood policy, development policy

\section{Introduction}

The study of the European Union's Security Strategy (ESS) reveals that the creation of stable states is considered as a prerequisite for international peace and stability. At the same time, domestic stability is associated with the establishment of democratic regimes. Consequently, democratization and democracy promotion can been seen as strategies that the EU seeks to employ in order to achieve international peace and security. But how has the EU sought to achieve these goals and what mechanisms has it used to promote democracy? The purpose of this paper is to address these fundamental questions. In doing so, it is divided into five sections. The first section discusses the EU's conception of the democracy-security/peace nexus and identifies how the EU has sought to achieve the democratization of third countries. The second section examines the idea and policy of 'conditionality', while the third section discusses how the implementation of EU conditionality affects and encourages the democratization of the candidate states. The fourth section focuses on the European Neighborhood Policy (ENP), which is particularly important for understanding democratization in the Mediterranean, Eastern Europe, and the Caucuses. The fifth and final section considers the importance of democratization on third states that are recipients of development aid.

\section{Democratization and Security}

The democracy-security nexus has been clearly established in the European Security Strategy which was adopted in 2003. Reading this document, one can easily observe that the EU has adopted a comprehensive understanding of the concept of security according to which threats to the security of any given state can arise both from within and outside its borders. As it has been stated in the ESS document, "The post-Cold War environment is one of increasingly open borders in which the internal and external aspects of security are indissolubly linked." In the summary of this document, it is also stated that "In the context of ever-increasing globalisation, the internal and external aspects of security are inextricably linked" (ESS, 2003:2).

Threats, according to the EU's conception of security, can operate not only in the military sector but also in the political, societal, economic, and environmental sectors. According to the European Security Strategy,

"Since 1990, almost 4 million people have died in wars, 90\% of them civilians. Over 18 million people world-wide have left their homes as a result of conflict. In much of the developing world, poverty and disease cause untold suffering and give rise to pressing security concerns. Almost 3 
billion people, half the world's population, live on less than 2 Euros a day. 45 million die every year of hunger and malnutrition. AIDS is now one of the most devastating pandemics in human history and contributes to the breakdown of societies. New diseases can spread rapidly and become global threats. Sub-Saharan Africa is poorer now than it was 10 years ago. In many cases, economic failure is linked to political problems and violent conflict" (ESS, 2003: 2).

Moreover, the European Security Strategy states that "Competition for natural resources - notably water - which will be aggravated by global warming over the next decades, is likely to create further turbulence and migratory movements in various regions. Energy dependence is a special concern for Europe" (EES, 2003:3).

Because of the interdependence of the security sectors, threats operating in one sector may lead to threat creation in other security sectors. For example, the European Security Strategy states that perceptions of globalisation as a cause of frustration and injustice have increased not only the scope for non-state groups to play a part in international affairs but they have also "....increased European dependence - and so vulnerability - on an interconnected infrastructure in transport, energy, information and other fields" (ESS, 2003:2).

The European Security Strategy identifies four key interrelated threats facing Europe. The first is terrorism, which not only puts lives at risk and imposes large costs, but it also "...seeks to undermine the openness and tolerance of our societies, and it poses a growing strategic threat to the whole of Europe" (ESS, 2003: 3). Terrorism is seen as being linked to violent religious extremism and arising out of complex causes, which include the pressures of modernization, cultural, social and political crises, and the alienation of young people living in foreign societies. (EES, 2003: 3).

The second key threat identified in the European Security Strategy is regional conflicts. For example, problems such as those in Kashmir, the Great Lakes Region and the Korean Peninsula are viewed as having a serious security "impact on European interests directly and indirectly", while "Violent or frozen conflicts, which also persist on our borders, threaten regional stability. They destroy human lives and social and physical infrastructures; they threaten minorities, fundamental freedoms and human rights" (ESS, 2003: 4). Conflict is also seen as leading to "extremism, terrorism and state failure and providing opportunities for organized crime. Moreover, regional insecurity can fuel the demand for WMD" (EES, 2003:4)

State failure is regarded as the third key threat for Europe. According to the European Security Strategy (2003: 4), "Bad governance - corruption, abuse of power, weak institutions and lack of accountability - and civil conflict corrode States from within... Collapse of the state can be associated with obvious threats, such as organised crime or terrorism." Consequently, state failure is viewed as an alarming phenomenon that undermines global governance, and adds to regional instability.

The fourth key threat to European security is organized crime which can have links with terrorism and, in extreme cases, can come to dominate the state. This internal threat to state security, according to the European Security Strategy, has an important external dimension: cross-border trafficking in drugs, women, illegal migrants and weapons accounts for a large part of the activities of criminal gangs. As it is stated in the ESS document, organized crime

“...can have links with terrorism. Such criminal activities are often associated with weak or failing states. Revenues from drugs have fuelled the weakening of state structures in several drug-producing countries. Revenues from trade in gemstones, timber and small arms, fuel conflict in other parts of the world. All these activities undermine both the rule of law and social order itself. In extreme cases, organised crime can come to dominate the state. $90 \%$ of the heroin in Europe... (ESS, 2003: 5).

In the "Report on the Implementation of the European Security Strategy" published in 2008, two particular type of threats gained prominence. The first is the growth in maritime piracy, which is regarded as a new dimension to organized crime (EC, 2008a: 8), and the second is climate change, which is viewed as a 'threat multiplier' (EC 2008a: 5). In this context, natural disasters, environmental degradation and competition for resources are seen as exacerbating conflict, especially in situations of poverty and population growth, with humanitarian, health, political and security consequences, including greater migration. Climate change is also regarded as leading to disputes over trade routes, maritime zones and resources previously inaccessible.

The European Security Strategy highlights the security-development nexus by stating that "Security is a precondition of development. Conflict not only destroys infrastructure, including social infrastructure; it also encourages criminality, deters investment and makes normal economic activity impossible. A number of countries and regions are caught in a cycle of conflict, insecurity and poverty" (ESS, 2003:2). In other words, there cannot 
be sustainable development without peace and security, and without development and poverty eradication there will be no sustainable peace. Human rights and good governance are seen as fundamental parts of the equation (EC, 2008a: 2). In other words, democratization - as linked to human rights and good governance - becomes the main instrument to achieve development and peace.

To address these threats, the European Security Strategy calls the EU Member States to “...think globally and to act locally" (ESS, 2003: 6). In practice, to defend its security and promote its values, the EU has intervened to help deal with regional conflicts and to put failed states back on their feet, including in the Balkans, Afghanistan, and in the DRC. Restoring good government to the Balkans, fostering democracy and enabling the authorities there to tackle organized crime has been seen as one of the most effective ways of dealing with organized crime (ESS, 2003: $6)$.

Building security in its neighborhood has been a priority for the European Union (EES, 2003: 7). Since democracy is linked to peace and security, it has been in the EU's interest that countries on its borders are well-governed. Neighboring states which are engaged in violent conflict, weak states where organized crime flourishes, dysfunctional societies or exploding population growth on its borders all pose problems for the European Union. Therefore, the integration of acceding states has been viewed as increasing EU's security. Consequently, the main EU task has been to promote a ring of well governed countries to the East of the EU and on the borders of the Mediterranean.

In a world of global threats, global markets and global media, EU's security and prosperity has been regarded as increasingly depending on an effective multilateral system. Consequently, the development of a stronger international society, well-functioning international institutions, and a rule-based international order has been identified as one of the fundamental EU security objectives (ESS, 2003: 9). This is the reason for which the EU has expressed its commitment to upholding and developing international law as well as contributing to the strengthening of international organizations, regimes, and treaties aimed at confronting threats to international peace and security.

What is fundamental, however, is the identification and highlighting of the democracy-peace nexus in the European Security Strategy according to which,

"The quality of international society depends on the quality of the governments that are its foundation. The best protection for our security is a world of well-governed democratic states. Spreading good governance, supporting social and political reform, dealing with corruption and abuse of power, establishing the rule of law and protecting human rights are the best means of strengthening the international order... As the world's largest provider of official assistance and its largest trading entity, the European Union and its Member States are well placed to pursue these goals" (ESS, 2003: 10).

Therefore, EU trade and development policies have become powerful tools for promoting democratic reforms in third states. Contributing to better governance through assistance programs, conditionality, and targeted trade measures have consequently become important features in EU's external policy (ESS, 2003: 10). According to the European Security Strategy, for states that have placed themselves outside the bounds of international society, it is desirable that they rejoin the international community and that the EU should be ready to provide assistance. However, for those "who are unwilling to do so should understand that there is a price to be paid, including in their relationship with the European Union" (ESS, 2003: 10).

Having examined how and why the EU sees the establishment of democracy as essential for the attainment of peace and development, the remaining of this paper will discuss how the policy of conditionality and the programs and measures associated with it contribute toward the democratization of states that wish to establish and maintain close relations with the European Union.

\section{EU Conditionality}

The pressures of international anarchy and the need of certain states to maintain close relations with a regional international organization in order to achieve their national goals and objectives enables the EU to define certain expectations and impose certain standards of behavior on the former. Therefore, EU pressures aimed at altering attitudes and policies can be equally applicable to all states irrespective of whether or not they seek EU membership.

The study of democratic consolidation includes, among other things, the study of international influences on democratization (Whitehead, 1996; Pridham, 2000). Among notions of international influences on democratization, 'conditionality' represents a deliberate effort to determine the process's outcome through 
external pressure. This is achieved by specifying conditions or even preconditions for support, involving either promise of material aid or political opportunities. A special version is 'democratic conditionality', which emphasizes respect for and the furtherance of democratic rules, procedures and values. While other international organizations make such conditionality demands, it is the EU, which, most of all, has elaborated an extensive policy of 'democratic conditionality'. The latter has considerable leverage because the prize for compliance on the part of applicant states is full EU membership and on the part of countries that wish to establish close relations with the EU is often financial and development assistance.

Because the EU started as an economic organization, the definition of the economic conditions that prospective member states or third countries should fulfill occurred from the very beginning. Since the European Economic Communities (EEC) was consisting of Western European capitalist states, 'economic conditionality' was not a crucial factor during the Cold War. It was the end of the Soviet Union, the collapse of communism in Eastern Europe, and the subsequent request of Eastern and Central European countries for EU membership that made 'economic' and 'political conditionality' a central feature of the EU enlargement (Kliewer \& Stivachtis, 2007: 146). The increasing role of the EU in world affairs also made 'economic' and 'political conditionality' a central feature of the EU's external policy.

Unlike 'economic conditionality', 'political conditionality' has been an essential feature of the EEC enlargement since the 1960s. The formulation of 'political conditions' has undergone considerable evolution over time expanded to include substantive democratic requirements. The real beginnings of 'political conditionality' thinking came in the early 1960s, when the issue of new membership was first under discussion although it did not actually take place until 1973. It was the European Parliament (EP) that took the initiative through its Political Committee to issue a report on the necessary political and institutional conditions for membership and association status of the EEC. The report stated clearly that "only states which guarantee on their territories truly democratic practices and respect for fundamental rights and freedoms can become members of the Community". The report also warned that "states whose governments do not have democratic legitimization and whose people do not participate in government decisions, either directly or through fully elected representatives, cannot aspire to be admitted into the circle of nations which form the European Communities" (Pridham ,2005: 30).

Subsequent developments related to the relations between the EEC and the authoritarian states in Southern Europe (Greece, Spain, and Portugal) proved essential in assisting the definition of 'political conditionality'. The formulation of 'political conditionality' became a more central and proactive part of the overall enlargement process, influenced partly by concern over special problems relating to post-communist politics (Pridham, 2002b: 205-6). Specifically, since the end of the Cold War in 1989, the EU (then EEC) has made assistance and institutional ties - first informally and later formally - conditional on the fulfillment of democratic and human rights standards. Generally, these conditions become more stringent as external countries seek to upgrade their institutional ties with and assistance by the European Union. In January 1989, the European Parliament demanded that "reference to human rights should figure" in the Trade and Cooperation Agreements the EEC was beginning to negotiate with the Central and Eastern European countries (CEECs) and should be mentioned specifically in the negotiating mandates given to the Commission. In April 1989, the European Council made resumption of the negotiations with Romania conditional upon the country's compliance with its human rights commitments in the CSCE framework. In November of the same year, the Paris European Summit established that "initiatives aimed at the countries of Eastern Europe as a whole are applicable only to those which re-establish freedom and democracy" (Schimmelfenning, Engert, \& Knobel, 2005: 30). During his visit to Belgrade in May and June 1991, Jacques Santer, President of the Council, stated that Yugoslavia's passage from the Cooperation agreement to association "hinges on political conditions such as ... progress in establishing democracy and respect for human rights and the rights of minorities" (Schimmelfenning, Engert, \& Knobel, 2005: 30).

After the dissolution of the Soviet Union, the European Commission confirmed that "negotiating ... new types of agreements has to be subject to political conditions." In May 1992, the European Council underscored that "respect for democratic principles and human rights ... as well as the principles of a market economy, constitute essential elements of cooperation and association agreements between the Community and its CSCE partners" (Schimmelfenning, Engert, \& Knobel, 2005: 30). Henceforth, the EU added a clause to the agreements that stipulated a suspension of the agreements if partner countries failed to comply with these principles. In November of the same year, the European Council approved guidelines for PHARE, the EEC's main program of assistance to the CEECs, which made aid conditional upon the "state of advance of the reforms in each of the beneficiary countries." On this basis, Croatia and Serbia-Montenegro have long been denied PHARE aid. In July 1993, the new regulations of the aid program for the former Soviet republics (TACIS) strengthened conditionality too: "the level and intensity of the assistance will take into account the extent and progress of reform efforts in the 
beneficiary country" (Schimmelfenning, Engert, \& Knobel, 2005: 30).

Finally, at its Copenhagen Summit in June 1993, the European Council established the "stability of institutions guaranteeing democracy, the rule of law, human rights and respect for and protection of minorities" as the sin qua non for accession to the European Union. Apart from defining the political conditions that candidate states should fulfill to gain entry into the EU, the Copenhagen Summit specified also the economic conditions that should be met before a candidate country is accepted as an EU member. Specifically, in order to quantify EU norms and values, the Copenhagen European Council established the following criteria:

1. Membership requires that the candidate country has achieved stability of institutions guaranteeing democracy, the rule of law, human rights, and respect for the protection of minorities.

2. Membership requires the existence of a functioning market economy as well as the capacity to cope with competitive pressure and market forces within the Union.

3. Membership presupposes the candidate's ability take on the obligations of membership including adherence to the aims of political, economic and monetary union.

The Copenhagen political and economic conditions have been elaborated on in the European Commission's (EC) Opinion of 1997 and from 1998 in the regular annual reports on candidate countries. The political conditions have been tied in with EU's programs of financial assistance, the accession partnerships, and the whole pre-accession strategy (Papadimitriou \& Phinnemore, 2004; Knill \& Lenschow, 2005). It is worth mentioning that additions have been made to the original criteria, notably in the inclusion of the fight against corruption, prompted by growing evidence of widespread corruption in most post-communist states.

Since the end of the Cold War, the protection of human rights and the attainment of good governance have been gradually becoming fundamental conditions in determining EU relations with its neighbors as well as the recipients of its development assistance.

\section{EU Conditionality and Candidate States}

Applicant states seeking admission into the EU hope to gain social, political, and economic benefits that are associated with being a member state. However, before the EU acknowledges an applicant state as a member, the applicant state's behavior must be modified to fit within liberal norms. Conditionality of acceptance uses a reward system to entice applicant states to adopt EU norms. The European Commission relies upon five 'levers' of conditionality: (1) access to negotiations and further stages in the accession process; (2) provision of legislative and institutional templates; (3) aid and technical assistance; (4) policy advice and twinning projects; (5) monitoring, demarches and public criticism (Grabbe, 2006: 261; 1999; 1998).

If the EU conditions are not met, the EU has three reinforcement strategies available for use: reinforcement by reward, reinforcement by punishment, and reinforcement by support (Schimmelfennig and Sedelmeir 2005a: 108; 2005b). Reinforcement strategies use social power to award desired behaviour while discouraging undesirable behaviour. According to Frank Schimmelfenning, reinforcement strategies differ from persuasion in two fundamental ways: first, reinforcement polices are exercised in an asymmetrical power structure where incentives and disincentives are used to entice applicants to adopt desired norms; and second, reinforcement polices look to modify state behavior over time (Schimmelfennig, Engert, \& Knobel, 2003: 498).

The substance of the reinforcement strategies involves two components: material incentives and social reinforcement (Schimmelfennig, 2005: 109). Material incentives involve tangible rewards. These rewards include but are not limited to the following: financial assistance, market access, technology experience and participation in decision. The second substantive component is social reinforcement. Schimmelfenning suggests that 'sociopsychological' rewards, such as international recognition and public praise influence applicant states to adopt desired norms (Schimmelfennig, 2005: 109).

The EU's potential for impacting democratization in candidate states varies between three broad stages: first, pre-negotiations (when the Copenhagen criteria have to be satisfied before negotiations commence); second, actual negotiations (when political conditions as updated are monitored regularly); and third, once membership begins when the EU's direct leverage over new entrants begins to weaken, but at the same time the indirect effects of European integration in helping to consolidate democracy increase through the very intensification of networking that goes with membership (Pridham, 2002a: 957). Although the deeper effects of integration are most likely through the embedding of new democracies within the EU itself, the most decisive stages when direct effects are most effective remain the pre-negotiation and accession negotiation ones. During the first phase, negotiations may be blocked by a country's failure to satisfy the political conditions, while during the second phase, 
negotiations may be interrupted or terminated if a negotiating country reverses its fulfillment of the political conditions, or chooses seriously to violate anyone of them.

The procedure for dealing with the failure of candidate states to meet the prescribed 'political conditions' is slow. At the beginning, there would be advance warnings in the annual regular report, and the European Commission would then set up an official visit to the country concern at the highest level. There would follow a period allowing for suitable action by the government. Failure to take any measures would be recorded in the next annual report. Eventually, if no measures are taken, then the matter would go to the European Council which would be responsible for halting negotiations for membership (Pridham, 2002a: 958). Thus political monitoring of applicant countries is almost continuous. This procedure reflects the EU view of democratization as a 'rolling process' and not as a state that is reached at a certain point of time.

Accession countries respond formally by making necessary institutional changes and passing relevant legislation. But their full satisfaction, including their implementation in practice, is not always easy to achieve due to financial, political and social constraints facing the candidate countries. The issue of implementing the 'political conditions' has come more to the fore, in parallel with the Commission's growing attention to implementation in the regular reports, specifically with regard to the acquis communautaire. Clearly, achieving this goes well beyond the official level, involving actors like non-governmental organizations (NGOs), political parties and the media, not to mention the need to convert economic interests and public opinion where necessary.

\section{Conditionality, Democratization and the European Neighborhood Policy (ENP)}

The European Neighborhood Policy (ENP) is a valuable tool for increasing democratization and securitization in the states surrounding the borders of the European Union. While candidate states have to follow the acquis for enlargement of the EU, there has been discussion regarding the specific role that the EU should take in the promotion of democratization in countries that are neither acceding countries nor candidates. As the European Commission states, the ENP is meant to allow member states to work "together with partner countries, to define a set of priorities, whose fulfillment will bring them closer to the European Union" (Commision Communication, 2004).

This differs from an external country like Turkey, which is governed on the basis of the Copenhagen criteria because of its status as a candidate for EU accession. The promotion of democracy, the rule of law, and a respect for human rights in third party states has long been a goal of the European Union (Commision Communication 2003). Yet, the EU delineates and distinguishes states that are candidate, potential candidates, and external states like those in Eastern Europe (Ukraine, Moldova, \& Russia) and the Mediterranean (including Morocco, Algeria, Tunisia, Egypt, Israel, Jordan, Lebanon, Syria, and the Palestinian Authority). More specifically, the ENP is addressed to those external states that have become neighbors due to EU enlargement over the last decade (Commision Communication, 2004). Even though candidacy may not be a short-term goal for some of these states, the EU nevertheless emphasizes the importance for building communication and shared values related to issues like security, democracy, human rights, political freedom, environmental protection, and trade liberalization. According to the EU, stability for not just the member states, but also the surrounding regions can be ensured much more effectively with attention paid to these areas, which are clearly interrelated and hard to untangle from one another.

According to the European Commission, there are many areas and situations that require attention in the aspect of assessing democratization and the protection of human rights, particularly in the Mediterranean (Commision Communication, 2003). Among them is a noticeable deficit in governance, which restricts the cultivation of shared democratic values. The marginalization of women and insufficiency of judicial systems in many countries also leads to a lack of political representation and development. Furthermore, democratization relies upon increased attention towards education programs, which often suffers funding inequality and inadequacy among external states. The Commission (Commission Communication, 2001) has laid out a set of policies that characterize the overall approach to democratization in external countries, and recommends:

1. The promotion of consistent policies among states;

2. Insisting upon a pro-active approach, focusing on political dialogue and assistance; and

3. The adoption of a strategic approach, focusing on the implementation of specific projects

As previously discussed, democratization is negotiated and enforced in candidate states within the European Union. However, the issue of democratization in third states is very important as well, especially as it constitutes a foreign policy issue for the European Union. It becomes clear that the EU uses financial and diplomatic means to ensure that there is a move towards democratization in third states. Even external states, in order to reap the 
benefits of the ENP, or often even to be a signatory to bilateral agreements with the EU, must show commitment to the respect of human rights, political freedoms, and democratization. Moreover, the EU holds that stability and security for the region depends upon a stronghold of democracy and democratic institutions and political freedoms in external states. In fact, the Union's neighbors, in order to take full advantage of the various benefits of the ENP, must pledge an adherence not only to human rights, but also to the values of democracy that the Union promotes. Turning attention to non-candidate states that are included in the Neighbourhood Policy allows for an analysis of the broad reaching scope of socialization and democratization.

The EU, through the Neighbourhood Policy, claims commitment to the "credible and sustained commitment towards democracy, the rule of law, respect for human rights, and progress towards the development of a market economy" in the Caucuses region, especially in Armenia, Azerbaijan, and Georgia. These common values also underlie the membership of Armenia, Azerbaijan and Georgia. These countries are also member of OSCE, which is another venue through which the EU monitors and reinforces the democratization efforts in the region.

In Eastern Europe, the outlier of Belarus provides a problem for the European Neighborhood Policy. Because of a serious lack of democratic structures and the absence of elections that meet international standards, Belarus is not able to take full advantage of the benefits of the European Neighbourhood Policy. Even though the Commission notes that the current regime in Belarus is far from democratic, it still maintains that democracy and the respect for human rights is a long-term goal for the Eastern European state. Indeed, as the Commission notes, when "fundamental political and economic reforms take place, it will be possible for Belarus to make full use of the ENP" (Commission Communication, 2004: 11). Despite the fact that many of the former neighbor states in Eastern Europe are now members of the EU or candidates for accession, there is still much attention focused on the promotion of standards of democracy in third states in the region. Especially with the eastward expansion of the $\mathrm{EU}$, the ENP uses the language of democratization as a way for extending the influence of the EU in the region, as well as a way to address various security concerns for the EU.

For the purposes of the Euro-Mediterranean partnership and the ENP third states, the Mediterranean is defined as including Morocco, Algeria, Tunisia, Egypt, Israel, Jordan, Lebanon, Syria, and the Palestinian Authority. Thus, the Mediterranean is an example of a group of states that are not candidates for accession, but do fall into the neighborhood status. Therefore the EU maintains that it is vital for the region to also work closely with European goals for democratization and the promotion of human rights and political freedoms. One example of these regional directives is the Euro-Mediterranean Partnership. The objectives of the EMP (Barcelona Process) are largely based on the fostering of a stabile region, committed to peace, democracy, and the protection of human rights and freedoms. The EU is so committed to this end that, "since 1992, the EC has included in all its agreements with third countries a clause defining respect for Human Rights and democracy as 'essential elements' in the relationship" (Commission Communication, 2003: 8).

The question then arises as to how to enforce these stipulations that may seem broad and ambiguous. Indeed, there is much debate as to how democracy should be defined, and in which contexts and how democratic principles should be insisted upon. Besides negotiation and diplomacy, financial incentives seem to be the most widely considered way of increasing democratization and the political liberalism in non-candidate countries. While the EU includes the language of democratization in agreements made with third states, unlike candidate states following the Copenhagen criteria, there are no clear, concrete political ramifications for third states that do not further pursue democratization. Economic incentives and positive conditionality, like the financial aid given to particular programs or organizations in third parties is a popular way for the EU to influence democratization measures. However, their effectiveness should also be taken with a grain of salt, as there may be concerns that the involvement with the EU in the Mediterranean can inadvertently support authoritarian regimes (Gillespie \& Whitehead, 2002: 198). Similarly, there could be concerns about coercion or regimes of governmentality in the region, yet this does not speak to the effectiveness of such policies and is beyond the scope of this chapter.

The EU, in an effort to increase political, social, and economic freedoms in the Mediterranean, as well as easing security concerns within Europe, has established a few key ways to promote democracy in the Mediterranean neighbor states. States that engage in political dialogue with the EU through the ENP can participate in bilateral agreements on an individual, state level. Additionally, any ENP state may be subject to direct questioning or inquiry on the part of the EU, with the same consideration given to the partners should there be a concern about human rights in the EU. It is important to note that, according to the EU, bilateral dialogue is not meant to be negative or accusatory in nature, but rather should provide the environment for cooperation.

The MEDA program is the key instrument through which the European Union provides support, both technical and financial, to making sure that economic and social restructuring can take place in third states. Thus, financial 
incentives and aid are a very important mechanism by which the EU can not only influence states, but also enforce and oversee democratization. Specific examples of MEDA's financial aid going towards democratic principles include recently supported programs in Algeria, Tunisia, Jordan and Egypt (Commision Communication, 2003). Because many of the principles on which the EU stands include free markets and trade liberalization measures, the economic incentive is arguably the easiest and most efficient way to govern the actions of third states. Indeed, this could also make the financial programs an area for critique, as they can be seen as the implementation of carrot and stick measures to utilize "soft power" in the regions surrounding the European Union. Nevertheless, the EU maintains that democratization and economic liberalism in the surrounding regions increases the security of third states, which necessarily increases the security of the member states. Thus, it is impossible to segregate the security concerns of the neighborhood regions from the security of the EU, especially with the recently intensified focus on the potential links between irregular migration, international smuggling, and terrorism.

Another mechanism that is used to encourage projects of democratization in the Mediterranean region is the European Initiative for Democracy and Human Rights (EIDHR). The European Parliament established the EIDHR in 1994 as a way to promote democratization in third countries. However, the EIDHR specifically focuses on the financial funding for activities conducted by non-governmental organizations operating in third countries. Because governments are not the beneficiaries of these funds, the EIDHR is meant to work alongside programs such as MEDA (Commision Communication, 2003). The potential for the EIDHR is greatest in promoting change and dialogue in civil society within third states, and therefore can act as a bridge between more structured reforms and the influence of values in a state. Civil society is a huge factor in the implementation and protection of human rights and democratization in third states.

Additionally, through setting up national and regional action plans, the EU has proposed to further increase the effectiveness of democratization in the Mediterranean, arguing that best practices should be identified and followed. Through all of these tools to promote democratization, it becomes clear that the EU is not solely interested in promoting democratic practices in candidate states. Even states that face virtually no realistic future of becoming a candidate for accession are still on the radar for democratization programs. There is a wide array of mechanisms that the EU uses to try to increase the shift towards democratization in the Mediterranean, in an attempt to promote economic and political stability for the EU as well.

\section{Democratization and Third States}

It is clear that the promotion of democracy is central to EU accession policies. In order for a state to become a new member of the EU, there must be a shown interest in the progress towards democratization and upholding the values of human rights. Moreover, as we have seen, the states that border the EU are also subject to the language of securitization through democratization. In order to secure its borders, the EU sets guidelines for states in its so-called "neighborhood." This assumed link between security and democratization translates to the EU's foreign policy, as well. Thus, the EU's sphere of influence expands far beyond states that make up the ENP.

The European Commission contends that stability and security are some of the most important factors for long-term engagement with third states. Thus, by focusing on good governance in some of the most politically unstable regions, the EU seeks to address "the root causes of conflict and insecurity" (European Commission, 2010b, p. 2). Established by the European Parliament in 1994, the European Initiative for Democracy and Human Rights (EIDHR) focuses precisely on the issue of democratization and the promotion on human rights in third countries (Commision Communication, 2003). This primarily takes place through funding activities of non-governmental and international organizations. In 2003, the annual sum for the worldwide projects amounted to $€ 100$ million. Thus, the EIDHR was established as a mechanism for cooperation and as a "financing instrument for the promotion of democracy and human rights worldwide" (European Commission, 2010b: 5). Even outside of the realm of influence that the EU has with its Neighborhood Policy, the core values involved with democratization are directly linked to security interests within EU discourse (European Commission, 2010b: 3). In particular, Afghanistan presents a major concern for the EU, and the Union maintains a long-term commitment to democratization and stability in the state, as well as its region (European Commission, 2010b: 3).

Indeed, as the European Commission argues, the EU seeks to integrate "human rights and democratization (sic) issues into all aspects of EU policy decision-making and implementation, including trade and external assistance (European Commission, 2008b: 1). In fact, Article 21 of the Treaty on European Union affirms that it is within the goals of the Union to promote democracy creation through all of its external actions (Council of the European Union, 2012). One cannot simply draw the conclusion, then, that the EU focuses on the promotion of democracy and human rights in states that directly affect its borders or ones that are potential members. According to this language, security of the EU does not begin and end simply at the external borders of the Union or its direct 
neighbors. Instead, the investment in political and economic development in other regions also affects perceptions of security and stability for the European Union. It is within discourses of global interconnectedness or globalization that these concepts become particularly salient, especially with the increased discussion of terrorism in the post-9/11 world (European Commission, 2010a). Thus, democracy and development are seen as 'global' values and are seen as requiring transnational cooperation and foreign aid. As Richard Youngs notes, a large notable and important component of the EU's aid budgets include assistance for democracy promotion and human rights (Youngs, 2003).

The EU notes that the fact that the organization is the world's largest aid donor demonstrates a commitment to poverty alleviation and economic development across the globe (Commission Communication, 2012: 1). The need to deliver aid, according to the 2012 Annual Report by EUROPEAID, cannot be removed from democratization efforts, or the further pursuit of human rights regimes (Commission Communication, 2012: 1). For example, the report places particular emphasis on the EU's relationship with Central Asian states, where it is "seen as a close political ally and trusted partner on whom they can rely on (sic) in the challenging transition process on which they have embarked" (Commission Communication, 2012: 5). Similarly, the EU-Latin America/Caribbean (LAC) Madrid summit in May 2010 outlined greater political relations with Central and South American countries. Even in Southeast Asia, the EU works towards strengthening bilateral partnerships with countries to increase the promotion of democratization in the region, in the hopes of securing other regions in order to secure EU's interests (Commission Communication, 2012: 6).

\section{Conclusion}

Since the end of the Cold War, the EU has been the stage of a large-scale project of international socialization (Flockhart 2005). When communism collapsed and the Soviet Union ceased to exist, European organizations proclaimed liberal democracy as the standard of legitimacy for the 'new Europe'. Among other European organizations, the EU assumed the task of inducting the ex-communist Central and Eastern European countries to this standard and devised several programs and institutional arrangements to assist and advance their democratic transformation. Among those programs and institutional arrangements, conditionality has played a major role in the socialization and democratization of candidate countries. But it is not only within candidate states that the strategy of democratization is deployed. The states that fall within the realm of the European Neighborhood Policy, as well as those states that lie outside of this sphere of influence, also are subject to the prioritization of democracy and human rights. Thus, one can draw from this that it is not simply about making the space within the EU democratic. Rather, the EU sees the promotion of democracy in regions across the globe as an issue that is relevant not just the regions involved, but also to European security. The language of security in EU documents is directly linked to the stability of democratic regimes throughout the world. Consequently, foreign aid and development assistance have been used as mechanisms for increasing the likelihood of states developing democratic practices.

\section{References}

European Commission. (2008a). Report on the Implementation of the European Security Strategy. Brussels, 11 December 2008.

European Commission. (2008b, December). Programming Guide for Strategy Papers: Democracy and Human Rights.

European Commission. (2003) European Security Strategy: A Secure Europe in a Better World. Brussels, 12 December 2003.

Flockhart, T. (Ed.). (2005). Socializing Democratic Norms. Basingstoke: Palgrave. http://dx.doi.org/10.1057/9780230523067

Gillespie, R., \& Laurence, W. (2002). European Democracy Promotion in North Africa: Limits and Prospects. Democratization, 9(1), 192-206. http://dx.doi.org/10.1080/714000242

Grabbe, H. (2006). The EU's Transformative Power: Europeanization through Conditionality in Central and Eastern Europe. Basingstoke: Palgrave.

Grabbe, H. (1999). A Partnership for Accession? The Implications of EU Conditionality for the Central and Eastern European Applicants. EUI.

Grabbe, H. (1998). Enlarging Europe Eastward. London: Cassell.

Kliewer, B., \& Yannis A. S. (2007). Democratizing and Socializing Candidate States: The Case of EU Conditionality. In Y. A. Stivachtis (Ed.), The State of European Integration (pp. 143-160). Aldershot: Ashgate. 
Knill, C., \& Lenschow, A. (2005). Compliance, Competition and Communication: Different approaches to European Governance and their Impact on National Institutions. Journal of Common Market Studies, 43(3), 583-606. http://dx.doi.org/10.1111/j.0021-9886.2005.00570.x

Papadimitriou, D., \& Phinnemone, D. (2004). Europeanisation, Conditionality and Domestic Change. Journal of Common Market Studies. 42(3), 619-639. http://dx.doi.org/10.1111/j.0021-9886.2004.00521.x

Pridham, G. (2005). Designing Democracy: EU Enlargement and Regime Change in Post-Communist Europe. New York: Palgave.

Pridham, G. (2002a). EU Enlargement and Consolidation Democracy in Post-Communist States - Formality and Reality. Journal of Common Market Studies, 40(3), 953-973. http://dx.doi.org/10.1111/1468-5965.00404

Pridham, G. (2002b). The European Union's Democratic Conditionality and Domestic Politics in Slovakia. Europe-Asia Studies, 54(2), 203-227. http://dx.doi.org/10.1080/09668130120116583

Pridham, G. (2000). The Dynamics of Democratisation: A Comparative Approach. London: Continuum.

Schimmelfenning, F., Engert S., \& Knobel, H. (2006). International Socialization in Europe: European Organizations, Political Conditionality and Democratic Change. Basingstoke: Palgrave. http://dx.doi.org/10.1057/9780230625129

Schimmelfennig, F., \& Sedelmeir, U. (2005a). The Politics of European Union Enlargement: Theoretical Approaches. London: Routledge.

Schimmelfennig, F., \& Sedelmeir, U. (Eds.) (2005b). The Europeanization of Central and Eastern Europe. Ithaca: Cornell University Press.

Schimmelfennig, F. (2005). The EU: Promoting Liberal Democracy Through Membership Conditionality. In T. Flockhart (Ed.), Socializing Democratic Norms. Basingstoke: Palgrave.

Schimmelfenning, F., Engert S., \& Knobel, H. (2003). Costs, Commitment and Compliance: the Impact of EU Democratic Conditionality on Latvia, Slovakia and Turkey. Journal of Common Market Studies, 41(3), 495-518. http://dx.doi.org/10.1111/1468-5965.00432

Whitehead, L. (Ed.). (1996). The International Dimensions of Democratization. Oxford: Oxford University Press.

Youngs, R. (2003). European approaches to democracy assistance: learning the right lessons? Third World Quarterly, 24(1), 127-138. http://dx.doi.org/10.1080/713701370

Commission Communication. (2001, May 8). The European Union's Role in Promoting Human Rights and Democratisation in Third Countries. COM(2001) 252 final.

Commission Communication. (2003, May 21). Reinvigorating EU actions on Human Rights and democratisation with Mediterranean partners. COM(2003) 294 final.

Commission Communication. (2004, May 12). European Neighbourhood Policy Strategy Paper. COM(2004) 373 final.

Council of the European Union. (2012, June 25). EU Strategic Framework andAction Plan on Human Rights and Democracy. 11855/12.

Commission Communication. (2012, August 6). Annual Report 2012 on the European Union's Development and External Assistance Policies and their Implementation in 2011. COM(2012) 444 Final.

European Commission. (2010a, April 1). European Instrument for Democracy and Human Rights (EIDHR) Strategy Paper 2007-2010.

European Commission. (2010b, April 21). European Instrument for Democracy and Human Rights (EIDHR) Strategy Paper 2011-2013.

\section{Copyrights}

Copyright for this article is retained by the author(s), with first publication rights granted to the journal.

This is an open-access article distributed under the terms and conditions of the Creative Commons Attribution license (http://creativecommons.org/licenses/by/3.0/). 